\title{
Streamlining management
}

\author{
Alan Bussey
}

This is the second in a series of articles on the white paper Working for Patients and its accompanying working papers. The first article by Ray Robinson on the new health care market was published last week (p 437).
Lewisham and North Southwark Health Authority, London SE1 9RY

Alan Bussey, FFCM, specialist in community medicine
The proposals in the white paper Working for Patients have been described as "the most far-reaching reform of the National Health Service in its forty year history." No one reading its hundred pages could disagree. Of the seven key measures proposed, those concerned with the governance of the NHS are as radical as any. There are differences of detail in the proposals for Scotland, Wales, and Northern Ireland but the principles are identical with those described here for England.

At the top level in England a new NHS policy board, chaired and appointed by the Secretary of State, will determine the strategy, objectives, and finances of the NHS. This board will also oversee the next level-the NHS management executive, which will deal with all operational matters in the NHS (including, for the first time, family practitioner committees) and will be led by a chief executive.

This structure is similar to that proposed in the first Griffiths report but never fully implemented. ${ }^{2}$ The new arrangements should be welcomed for removing the confusion between policy setting and management that led to the present NHS Management Board being chaired successively by the first chief executive, ministers of state, and, latterly, the Secretary of State - to the bewilderment of the rest of the NHS.

At the next level down regional health authorities are to remain but are to concentrate on setting performance criteria for and monitoring the performance of those below them and evaluating the effectiveness of the NHS. They will shed many of the support services that can better be provided by district health authorities, agencies, or the private sector. The legal, information, building, and works bureaucracies of regional health authorities are among those that will lose their monopoly position and will have to compete or die. The remit of regional health authorities will be extended to embrace family practitioner committees as well as district health authorities-bringing together for the first time at a strategic level the main arms of the NHS.

\section{Delegation to units}

District health authorities are similarly to be slimmed by further delegation to units - particularly to major hospitals. In the words of the white paper "like regional health authorities, district health authorities can then concentrate on ensuring that the health needs of the population for which they are responsible are met; that there are effective services for the prevention and control of diseases and the promotion of health; and that their population has access to a comprehensive range of high quality, value-for-money services."

The governance of both regional health authorities and district health authorities will be changed dramatically by fusing the management team with an authority whose membership is reduced in size. The new authorities will be composed of five non-executive members, up to five executive members (managers), and a non-executive chairman. Membership places reserved for local authority, trade unions, medical, and nursing nominees are swept away with the sole exception of a medical school representative on authorities in teaching districts.
As well as losing their direct link with the Department of Health family practitioner committees are to be reduced in size in line with other authorities from 30 members to 11 . There will be five lay members and four professionals (instead of the present 15) including one doctor in general practice. Together with the chairman, the committee will appoint the eleventh member-the chief executive. This post will carry wider responsibilities and scope than do present family practitioner committee administrators. Consequently, salaries will be higher and the posts will be open to competition from managers inside and outside the NHS.

Finally, a new kind of management authority is to be created in the self governing hospitals. These hospitals will have a substantial degree of independence within the NHS and each will be run by an NHS hospital trust. Their boards of directors will have no more than 11 members (including the chairman) with a balanced number of executive and non-executive directors. Two of the latter will be drawn from the local community associated with the hospital; employees of the NHS are barred. The executive directors, however, will include a medical director and a senior nurse manager in addition to the finance director and the general manager. To be permitted to achieve self governing status hospitals must show that they are well managed at present and senior professional staff, especially consultants, must be concerned in the management of the hospital.

Two important themes run through these organisational changes. The first begins the separation of the commissioning or buying of health services from their provision. The second takes further the managerial revolution in the NHS by slimming health authorities and tailoring them more closely to a management role, thereby ending all pretence to a representative function. As part of this aim consultants are to be given greater opportunities to manage hospitals and their services, but the medical presence on authorities above hospital level, as of right, is lost.

\section{Ending a period of confusion}

Whatever views may be expressed for or against this approach the removal of the representative element will end a long period of confuison. There is no doubt that many district health authority members, for example, have found it difficult to see a clear role for themselves sinçe the introduction of general management. This dilemma has been particularly acute for generalist members when decisions on closures or reductions in service have been required. Many have been torn between their concern for the effects on the population for which they feel responsible and their corporate management responsibility.

The problem has been different for local authority members. Their contributions and reactions to unpleasant decisions have often been frankly political, reflecting the views of their particular party in an almost reflex way. It seems likely that this partisan approach by some local authority members has contributed to their exclusion from the new arrangements. 
While this exclusion may help the new authorities to focus on the tasks of management by removing the representational distraction, there will be losses too. In several health authorities the local authority members have provided an invaluable link with the social services, education, environmental health, and housing committees of their authorities. These services are key partners in many health authority plans and initiatives, and the more thoughtful and less strident local authority members have often been able to oil the committee and financial wheels to make things happen. It may be that the long delayed government response to the Griffiths report on community care will provide alternative mechanisms. ${ }^{3}$ It is difficult to see, however, any alternative that will adequately replace the intimate knowledge which many local authority members now have of the strategies and plans of both sides.

A third group of members of present authorities are the professionals - the consultant, general practitioner, and nurse members. Appointed for their personal qualities rather than as lobbyists for their professional constituencies, they have contributed a skill that has illuminated many debates and has been valued by lay members and chairmen alike. They have often been torn in the same way as have the generalist members but with the added burden of their knowledge of the aims, pressures, and frustrations of medicine and nursing in the NHS. The white paper's proposals seem to rule out this kind of contribution in future because no place is reserved for doctors in the non-executive membership of the new health authorities, save for the lone general practitioner on the family practitioner committee. The profession will no doubt wish to explore in discussions with the government whether doctors are to be appointed nonexecutive members of health authorities "on the basis of the skills and experience they can bring to the authority," to quote the white paper.

\section{Medical input to health authorities}

If they are not other areas become crucially important to the profession in terms of medical input to health authorities. Perhaps the most important is executive membership, where there are several possible ways to include doctors. Five executive members (managers) are proposed for regional health authorities and district health authorities with places already identified for the finance director and general manager. Few districts have a medically qualified district general manager but more have doctors managing large units. So the opportunity exists in many district health authorities for management arrangements to be made to enable clinician managers to become executive members of authorities (at least until their hospitals become NHS hospital trusts) in the same way as the white paper describes how clinicians can become executive directors on the boards of self governing hospitals.

A second route to member level flows from the new emphasis on the responsibilities of authorities to ensure that the health needs of their population are met; that there are effective services for the prevention and control of diseases and the promotion of health; and that their population has access to a comprehensive range of high quality, value for money services. To discharge these functions it will be essential for the regional health authority or district health authority to appoint its director of public health (on whose annual report on the health of the population many of the authority's decisions will be based) as an executive director.

Another important avenue for medical input to management is, of course, the medical advisory
But the real joker in the restructuring pack is the proposal for general practitioners to hold budgets and contract for services. If this initiative prospers and most general practitioners take on these responsibilities and become skilled at them they will resemble health maintenance organisations on the American model more and more. General practitioners and their teams will then be providing preventive and primary care, buying secondary care from hospitals, and then providing aftercare back in the community. If there is a role for health authorities at any level it is likely to be reduced to financial allocation and perhaps the monitoring of quality and outcome.

machinery of regional health authorities, district health authorities, and family practitioner committees. This will assume much greater importance to the profession and I hope to the health authorities as well. In many districts and some regions and family practitioner committee areas this will require an overhaul of the profession's machinery and improvement in the content and quality of discussions if authorities are to take any notice.

A third, albeit more remote, route for medical input will be the local community health council. The removal of the last vestige of the consumer role of health authorities leaves this way clear for community health councils. The profile of many of them will be raised, not least because local authorities excluded from health authority membership in future will see community health councils as a natural platform for political or non-political debates about health. In consequence, some community health councils may be hijacked by local authorities, but all should see the quality of their membership, information, and debates improved. In these circumstances the profession locally would do well to consider closer links with community health councils.

In a changing landscape there is one certainty and several possibilities. That certainty is that the structural reforms will occur. No working papers or debates seem to be contemplated on this part of the white paper. So, by April 1991, restructured regional health authorities, district health authorities, and family practitioner committees will be in place together with an unknown number of NHS hospital trusts.

Turning to possibilities, if implementation continues beyond the next general election more and more district health authorities will lose their acute hospitals and perhaps other services. They will turn their attention from direct management of the provision of care to analysing the needs of their populations, planning and purchasing packages of services to meet those needs, and evaluating the results in terms of quality and outcome. Many district populations are too small to carry out these functions efficiently or effectively. Moreover, there are insufficient numbers of people with skills in these areas to cover 200 authorities. Mergers of districts with each other and with family practitioner committees as foreshadowed in the white paper are likely to follow. If as a result of this the number of authorities is reduced to, say, 50 or 60 questions will then arise about the continuing roles of regional health authorities, which, by then, would have only three or four authorities below each of them.

When considering all these possibilities doctors, managers, and patients alike may perhaps be forgiven for echoing Sam Weller in Pickwick Papers when he said "in which case it gets too excitin' to be pleasant."

1 Secretaries of State for Health, Wales, Northern Ireland, and Scotland. Working for patients. London: HMSO, 1989. (Cmnd 555.)

2 NHS Management Inquiry. Report. London: DHSS, 1983. (Griffiths report.)

3 Griffiths R. Community care: agenda for action. London: HMSO, 1988. 